\title{
Automotive Vocational High School: How Career Guidance and Parents Support Impact the Students' Work Readiness
}

\author{
Purnawan*, Budi Santosa, Arief Kurniawan, Ananda Rizky Hakim \\ Universitas Ahmad Dahlan, Jl. Pramuka No. 42, Pandeyan, Umbulharjo, Yogyakarta, Indonesia \\ ${ }^{*}$ Corresponding author, e-mail: purnawan.purnawan@pvto.uad.ac.id
}

\begin{abstract}
This study aims to determine the contributions of career guidance and parents support to the vocational high school students' work readiness. This research is survey. The sampling technique used a proportional random sampling method. The data collection used the questionnaire method to obtain career guidance data, support parents, and students' work readiness. The data analysis included descriptive analysis, prerequisite analysis including normality test, linearity test, and multi-collinearity test, and multiple analysis with F-test, determination test, and partial correlation analysis. The results showed that (1) career guidance and parents' support influenced positively and significantly to work readiness of vocational students, (2) career guidance influenced positively and significantly to work readiness of students in vocational school, and (3) the parental support influenced positively and significantly on work readiness of students in vocational high schools.
\end{abstract}

Keywords: career guidance, parents support, working readiness

How to Cite: Purnawan, P., Santosa, B., \& Kurniawan, A. (2020). Automotive vocational high school: How career guidance and parents support impact the students' work readiness. Journal of Vocational Education Studies, 3(1), 61-70. DOI: https://doi.org/10.12928/joves.v3i1.2142.

\section{INTRODUCTION}

The development of science, technology, and the demands of globalization have resulted in the increasingly fierce competition in the provision of superior human resources. To be able to continue to maintain competitiveness, existing human resources are required to continue to improve their knowledge, skills, attitudes, and values or competencies, so that everyone must be able to become a lifelong learner. Many factors determine the quality of education, but teachers are still seen as the main determining factors, because teachers are in control of learning, determine the direction of achieving learning objectives, and manage to learn (Amir, 2013; Kunandar, 2007; Jalal, 2007).

Described in the Law Number 20 of 2003, concerning the National Education System article 15, vocational secondary education (SMK) aims to prepare students, especially to work in certain fields. Vocational schools are directed to form students ready to work, but the preparation of middle-level workforce is not an easy thing. The existence of vocational schools in preparing middle-skilled workers who are still skilled needs to be improved. Not all SMK graduates can meet the demands of employment, and this is due to the gap between the skills possessed by SMK graduates and the skills needed in the world of work. This is evidence from the Data of Population Aged 15 Years and Over Who Worked according to the Highest Education Completed in 2017-2018 at the Central Statistics Agency (BPS) 2019, which showed a decrease in the absorption capacity of SMK graduates into the world of work. The absorption capacity of SMK graduates into the world of work in February 2017 was 9.27 million, in February 2018 as many as 8.92 million, and in February 2019 as many as 8.63 million.

A statement from the Manpower and Transmigration Office of Kulon Progo said that the work readiness of SMK graduates in Kulon Progo is still lacking. He conveyed this indication by paying attention to the SMK graduates they distributed to industry, many returned home after working for several months. The level of work readiness of vocational 
students is influenced by many factors including motivation, skills, external practice experience, career guidance, parents' economic background, previous learning achievements, job information, mentality, interest, and expectations of entering the workforce (Sukardi, 2008:44).

In general, a person's readiness to enter the workforce involves three factors, namely: physiological, experiential, and psychological factors (Mariah \& Gandhi, 2010). Work readiness by Makki et al. (2015), is the skills, knowledge, and attitudes that will make it possible to help new graduates to contribute productively to the achievement of organizational goals in the place where the individual works, according to (Sofyan, 1991), is an ability someone to complete a job in accordance with the provisions without experiencing difficulties and obstacles with maximum results with a predetermined target, while according to Sugihartono (1991) and Fitriyanto (2006), work readiness is a condition that indicates the harmony between physical maturity, mental maturity, and learning experience so that individuals have the ability to carry out certain activities or behaviors in relation to work.

To prepare school students to seek career guidance services in counseling guidance to further mature student work readiness. Winkel (2014:114) argues that career guidance is guidance in preparing for the world of work, in choosing employment or certain positions/professions and in providing oneself to be ready to assume that position, and in adjusting to the various demands of the job fields entered, according to Marsudi (2010:123) career guidance is to provide assistance to individuals in choosing and making decisions both in relation to their work and future.

Parental support will also be very necessary for children to realize their ideals. Parental social support can originate from internal social support, such as husband or wife support and sibling support, or external parent support such as relatives, cousins, etc. (Friedman, 2008). According to Lee \& Detels (2007), parental support can be divided into two things, namely positive support, and negative support. Positive support is positive behavior shown by parents, and negative support is behavior that is considered negative that can lead to the negative behavior of children. With the attention of parents expected to provide enthusiasm for learning and trying to achieve achievements or ideals.

\section{RESEARCH METHOD}

This research is included in quantitative research that uses survey research designs. Research is by students majoring in light engineering vehicles in five private SMK in Kulon Progo. The population in this study was class XII students majoring in TKR. The sampling technique using a proportional random sampling method. The data collection technique in this study was a questionnaire technique. Data analysis techniques included descriptive analysis and analysis prerequisite tests include normality test, linearity test, and multicollinearity test, multiple analysis with $\mathrm{F}$ test and determination test, and partial correlation analysis.

\section{RESULTS AND DISCUSSION}

\section{Work Readiness}

The students' work readiness in SMK in Kulon Progo is presented in Table 1.

Table 1. Descriptive analysis of student work readiness

\begin{tabular}{lcccc}
\hline & Frequency & Percentage & Valid percentage & Cumulative percentage \\
\hline Poor & 49 & 26.1 & 26.1 & 26.1 \\
Good & 89 & 47.3 & 47.3 & 73.4 \\
Very good & 50 & 26.6 & 26.6 & 100 \\
Total & 188 & 100,0 & 100.0 & \\
\hline
\end{tabular}

Volume 3, Number 1, May 2020 
According to Table 1, the majority of students in private vocational high school in Kulon Progo have the work-readiness of students who belong in both categories with a total of 89 students or $47.3 \%$. Besides this number, there are private vocational school students in Kulon Progo who have work readiness in the excellent category with a total of 50 students or $26.6 \%$. However, there are still private vocational school students in Kulon Progo who have work readiness in the poor category with 49 students or $26.1 \%$.

\section{Career Guidance}

The students' career guidance in SMK in Kulon Progo is presented in Table 2.

Table 2. Descriptive analysis of students' career guidance

\begin{tabular}{lcccc}
\hline & Frequency & Percentage & Valid percentage & Cumulative percentage \\
\hline Poor & 46 & 24.5 & 24.5 & 24.5 \\
Good & 98 & 52.1 & 52.1 & 76.6 \\
Very good & 44 & 23.4 & 23.4 & 100 \\
Total & 188 & 100.0 & 100.0 & \\
\hline
\end{tabular}

Based on Table 2, the majority of students in vocational Private in Kulon Progo has a Career Guidance belonging to the categories with the number as many as 98 students or $52.1 \%$. In addition to this number, there are Private Vocational School students in Kulon Progo who have Career Guidance in the excellent category, with a total of 44 students or 23.4\%. However, there are still private vocational students in Kulon Progo who have Career Guidance in the bad and very bad categories. Private SMK students in Kulon Progo who have career guidance in the bad category are 46 students or $24.5 \%$.

\section{Parental Support}

The students' parental support in SMK in Kulon Progo is presented in Table 3.

Table 3. Descriptive analysis of parental support

\begin{tabular}{lllll}
\hline & Frequency & Percentage & Valid percentage & Cumulative percentage \\
\hline Poor & 33 & 17.5 & 17.5 & 17.5 \\
Good & 87 & 46.3 & 46.3 & 63.8 \\
Very good & 68 & 36.2 & 36.2 & 100.0 \\
Total & 188 & 100.0 & 100.0 & \\
\hline
\end{tabular}

Based on the table above, it can be seen that the majority of students in private vocational schools in Kulon Progo have the support of parents belonging to either category with a total of 87 students or $46.3 \%$. Besides this number, there are Private Vocational School students in Kulon Progo who have the support of parents in the excellent category with a total of 68 students or $36.2 \%$. However, there are still private vocational students in Kulon Progo who have parental support in the poor category. Private SMK students in Kulon Progo who have parental support in the poor category are 33 people or $17.5 \%$.

\section{Prerequisite Test Analysis}

Normality test

The normality test is carried out by the Kolmogorov-Smirnov Test or K-S Test, as presented in Table 4. 
Table 4. Normality test results

\begin{tabular}{lccc}
\hline \multicolumn{1}{c}{ Variable } & Z-value of K-S & Sig.(2-tailed) & Information \\
\hline Working readiness (Y) & 1.148 & 0.143 & Normal \\
Career guidance (X1) & 1.194 & 0.116 & Normal \\
Parental support (X2) & 1.105 & 0.174 & Normal \\
\hline
\end{tabular}

The data normality test results with the Kolmogorov-Smirnov Test showed that the significance value of all data in each variable> 0.05 , namely 0.143 work readiness variables, 0.116 career guidance variables, and 0.174 parent support variables. A Significance value greater than 0.05 indicates that the data are normally distributed. Thus, it can be said that the research data meets the prerequisites for normality.

\section{Linearity Test}

Table 5. Linearity test results

\begin{tabular}{|c|c|c|c|}
\hline Relationship & $\mathrm{F}$ & Sig & Information \\
\hline $\begin{array}{l}\text { Working readiness }(\mathrm{Y})^{*} \\
\text { Career guidance }(\mathrm{X} 1)\end{array}$ & $\begin{array}{l}25.9 \\
57\end{array}$ & 0,000 & $\begin{array}{l}\text { There is a linear } \\
\text { relationship }\end{array}$ \\
\hline $\begin{array}{l}\text { Working readiness }(\mathrm{Y})^{*} \\
\text { Parental support }(\mathrm{X} 2)\end{array}$ & $\begin{array}{l}62.2 \\
47\end{array}$ & 0,000 & $\begin{array}{l}\text { There is a linear } \\
\text { relationship }\end{array}$ \\
\hline
\end{tabular}

The table above shows that all significance values of the relationship between each independent variable are smaller than 0.05 . This shows that all independent variables have a linear relationship with the dependent variable. Thus, it can be concluded that the data meet the prerequisites for the linearity of the relationship.

\section{Multi-collinearity test}

Multi-collinearity test to find out the relationship between several or variables explained in the regression model. To detect whether a linear regression model experiences multicollinearity can be examined using the tolerance value and the value of Variance Inflation Factor (VIF) for each independent variable.

Table 6. Multi-collinearity test results

\begin{tabular}{clll}
\hline & \multicolumn{2}{l}{ Collinearity Statistic } & Information \\
& Tolerance & VIF & \\
\hline Career Guidance (X1) & 0,59 & 1,685 & There is no multicollinearity \\
Parental support (X2) & 0,69 & 1,445 & There is no multicollinearity \\
\hline
\end{tabular}

Multi-collinearity test to find out the relationship between several or variables explained in the regression model. To detect whether a linear regression model experiences multi-collinearity can be examined using the tolerance value and the value of Variance Inflation Factor (VIF) for each independent variable.

\section{Hypothesis Test Results in}

Hypothesis Test 1

The hypothesis test is carried out by the linear regression, as presented in Table 7. 
Table 7. Test results of $F$

\begin{tabular}{|c|c|c|c|c|c|c|}
\hline Model & $\begin{array}{l}\text { Sum of } \\
\text { Squares }\end{array}$ & $\mathrm{df}$ & $\begin{array}{l}\text { Mean } \\
\text { Square }\end{array}$ & $\mathrm{F}$ & Sig & Information \\
\hline 1 Regression & 14881.586 & 3 & 4960.52 & 1215. & 0,000 & Very \\
\hline Residual & 750.898 & 181 & 9 & 528 & & significant \\
\hline Total & 15632.484 & 187 & 4.081 & & & \\
\hline
\end{tabular}

F test results show a significance value smaller than $0.05,0.000$. Significance value that is smaller than 0.05 indicates that career care and parental support together have a very significant influence on student work readiness. Thus, the research hypothesis H1 can be accepted, namely " Career guidance and support of the parents together and very significant positive effect on job readiness vocational students Private all Kulon Progo". The results of the $\mathrm{F}$ test also showed that the regression model obtained was appropriate as a model for predicting work readiness of students of Private Vocational Schools in Kulon Progo.

The test results of determination on the guidance careers, and support from parents on the readiness of the students' work can be seen in the following table:

Table 8. Determination Test Results

\begin{tabular}{crrrr}
\hline Model & $\mathrm{R}$ & R Square & $\begin{array}{c}\text { Adjusted R } \\
\text { Square }\end{array}$ & $\begin{array}{c}\text { Std. Error } \\
\text { of the } \\
\text { Estimate }\end{array}$ \\
\hline 1 & 0,976 & 0,952 & 0,951 & 2,020 \\
\hline
\end{tabular}

The table above shows that the test results obtained value of $\mathrm{R} 2$ of 0.952 ; this means that approximately $95.2 \%$ of vocational student's work readiness Private all Kulon Progo directly affected by predictor variables were estimated, namely career guidance, and support from parents. However, as much as $4.8 \%$ is influenced by other factors not included in the estimated model of multiple regression analysis conducted. The results of the regression analysis in this test can be seen in the Table 9.

Table 9. Results of Multiple Regression Analysis

\begin{tabular}{llrc}
\hline & & \multicolumn{2}{c}{ Unstandardized Coefficients } \\
\cline { 3 - 4 } & & $\mathrm{B}$ & \multicolumn{1}{c}{ Std. Error } \\
\hline 1 & Constant & 3.833 & 1.216 \\
& Career guidance (X1) & 0.366 & 0.121 \\
& Parental Support (X2) & 0.895 & 0.083 \\
\hline
\end{tabular}

From the Table 9, the regression equation model of test results can be arranged as follows.

$$
\begin{gathered}
Y=a+b 1 X 1+b 2 X 2 \\
Y=3.833+0.366 X 1+0.895 X 2
\end{gathered}
$$

The table and equations above can be interpreted as follows. A positive constant 3,833 can be interpreted that if career guidance and parental support are constant, then student work readiness is valued at 3.833. A positive regression coefficient b1 of 0.366 can be interpreted that if career guidance increases by 1 unit, the student's work readiness increases by 0.366 , The positive influence of career guidance shows that the career guidance score is in line with the student's work readiness score. In a sense, the higher the career guidance score, the higher the student work-readiness score. This condition shows 
that if there is an increase in career guidance, the work readiness of students also experiences an increase. Positive regression coefficient b2 0.895 can be interpreted that if the support of parents increased by 1 unit, then the work readiness of students increased by 0.895 . The positive influence of parental support shows that the score of parental support is in line with the student work-readiness score. In a sense, the higher the score of parental support, the higher the student work-readiness score. Conversely, the lower the parent's support score, the lower the student's work readiness score. This condition shows that if there is an increase in parental support, the work readiness of students also experiences an increase, or if there is parental support, then the readiness of student work can decrease.

Hypothesis test 2

The result of partial correlation analysis is presented in Table 10.

Table 10. Results of the Partial Correlation Analysis of Hypothesis 2

\begin{tabular}{|c|c|c|c|c|}
\hline \multirow{2}{*}{ Model } & \multirow[t]{2}{*}{ Sig. } & \multicolumn{3}{|c|}{ Correlations } \\
\hline & & Zero-order & Partial & Information \\
\hline 1 Career guidance (X1) & 0,003 & 0,957 & 0,218 & Very significant \\
\hline
\end{tabular}

Based on the table above, it can be seen that the correlation coefficient is 0.218 , with a significance value of 0.003 . The significance value of less than 0.05 indicates that the relationship that occurs between career guidance and student work readiness is a very significant relationship. Thus the hypothesis 2 of the study can be accepted, namely: "Partial career guidance has a positive and very significant effect on the readiness of work of students in Private Vocational Schools in Kulon Progo." This means that the higher the career guidance of students, the higher the work readiness of students. And vice versa, the lower the career guidance of students, the lower the work readiness of these students.

From Table 10, it can be seen that the zero-order correlation coefficient is 0.957 , whereas after the career guidance variable is controlled, the correlation coefficient becomes 0.218 . Thus, there is a decrease in the correlation after the parent support variable and work culture that is controlling or is constant. Thus, it is understood that if parent support and career guidance are constant, then the positive relationship between career guidance and student work-readiness will decrease. These results indicate that the relationship between career guidance and work readiness is controlled by parental support and work culture.

\section{Hypothesis test 3}

Hypothesis 3 test is done by partial correlation analysis. The results of partial data correlation analysis can be seen in Table 11.

Table 11. Results of the hypothesized partial correlation analysis 3

\begin{tabular}{cccccc}
\hline & Model & Sig. & \multicolumn{3}{c}{ Correlations } \\
\cline { 3 - 5 } & & Zero-order & Partial & Information \\
\hline 1 & Parental Support (X2) & 0,000 & 0,971 & 0,623 & Very significant \\
\hline
\end{tabular}

Based on the table above, it can be seen that the correlation coefficient is 0.623 , with a significance value of 0.000 . the significance value of less than 0.05 indicates that the relationship that occurs between parental support and student work readiness is a significant relationship. Thus, hypothesis 3 of the study can be accepted, namely: "Parental support partially has a positive and significant effect on the readiness of student work in

Volume 3, Number 1, May 2020 
Private Vocational Schools in Kulon Progo ". This means that the higher the support of parents, the higher the work readiness of students. And vice versa, the lower the support of parents, the lower the work readiness of students.

From Table 11, it can be seen that the zero-order correlation coefficient is 0.971 , whereas after the parent support variable is controlled, the correlation coefficient becomes 0.623 . Thus, there is a decrease in the correlation after the career guidance and work culture variables that control or are constant. Thus, it is understood that if career guidance and work culture are constant, then the positive relationship between parental support and student work-readiness will decrease. These results indicate that the relationship between parental support and student work readiness is controlled by career guidance and work culture.

\section{Effects of career guidance and parental support on student work readiness}

Research shows that career guidance and support parents in Together effect on the readiness of the students' work. The results of the analysis found that there is significant influence and this contribution at him positively to two independent variables jointly between career guidance and support for parents on job readiness on vocational students Private engineering light vehicles se Kulon Progo through regression equation possessed of each independent variable is good enough, so that it can explain work readiness. In accordance with the hypothesis proposed in this study, career guidance and support from parents together with a very significant positive effect on job readiness vocational students Private all Kulon Progo . The better career guidance provided by the school for its desire to work, and the higher the support of parents in students owned both in the affective, cognitive, and psychomotor fields, making students motivated and ready to go into the world of business or industry in accordance with competence possessed. Judging from the magnitude of the contribution of influence to the two variables partially from each variable (career guidance, and parental support) with work readiness for this regression coefficient is significant.

The description above shows that even though the two independent variables (career guidance and parental support) significantly influence both partially and simultaneously. Judging from the characteristics of the two independent variables are: career guidance and parental support are variables that are still possible to develop in each individual. In order to achieve good work readiness for each individual, it needs to endeavor or well-conditioned so that the two variables can be increased in intensity for each individual with various efforts that can be carried out by various parties, especially the school.

\section{Effect of Career Guidance on Student Work Readiness}

The results of the analysis show that career guidance provides a significant determination of vocational student work readiness. These results indicate that career guidance provides high determination in relation to increasing student work readiness. These findings indicate that students can understand their potential, and understanding of the world of work, so students have the readiness to enter the workforce, both as workers and trying to be independent as entrepreneurs. As explained by Winkel (2014:114), career guidance is guidance in preparing to face the world of work, in choosing employment or certain positions/professions and equip yourself to be ready to assume that position, and in adjusting to the various demands of the job field that entered. Next results of this research were supported by the theory of Marsudi (2010:123) is career guidance provides assistance to individuals in choosing and making a good decision to do with work and the future. Career guidance services are inseparable from the basic concepts of guidance and counseling, which helps students to understand their potential and understand their 
environment. The target of career guidance service material at this school is aimed at middle school students, so the purpose of career guidance also refers to parental support provided by parents is at a moderate level and even tends to be at a the needs and whereabouts of middle school students.

\section{Effects of Parental Support on Student Work Readiness}

Judging from the results of the analysis of the thesis shows that very high level. The results of the study are in accordance with the theory of Lee \& Detels (2007), parental support can be divided into two things, namely, positive support and negative support. With the attention of parents expected to provide enthusiasm for learning and trying to achieve achievements or ideals. The explanation above is different from the research conducted by Annisa (2017) which shows that there is no correlation and there is no significant correlation between parents 'support and the work-readiness of students at SMK Negeri 1 Tenggarong, because there are many things that affect the readiness of vocational students' work, not just parent support. Thus the relationship of parental support with student work readiness is negative. The explanation above is different from the results of the study, which shows that there is no correlation, and it is significant, this is because there are many things that can affect the work readiness of vocational students, not just the support of parents.

\section{CONCLUSION}

The conclusions obtained from the results of the study are described as follows. First, the contribution of career guidance and parental support together has a positive and very significant effect on the work readiness of Private Vocational School students in Kulon Progo, majoring in TKR. Thus it can be seen that if the contribution of career guidance, and good parental support, the work readiness of private vocational students in Kulon Progo will increase as well, and vice versa if the contribution of career guidance and parental support decreases jointly then job readiness Private Vocational School students in Kulon Progo will also experience a decline.

Second, the contribution of career guidance partially has a positive and very significant effect on the work readiness of private vocational students in Kulon Progo, majoring in TKR. There is a positive and very significant influence on career guidance on the work readiness of private vocational students in Kulon Progo TKR majors, indicating that the higher the career guidance, the higher the work readiness of students. And vice versa, the lower the career guidance, the lower the work readiness of the student.

Parental support is a partially positive and significant effect on the work readiness of private vocational students in Kulon Progo TKR majors. There is a positive and significant influence of parental support on the work readiness of private vocational students in Kulon Progo, majoring in TKR. The positive influence of parental support shows that the better the support of parents, the better the work readiness of students. And vice versa, the lower the support of parents, the lower the work readiness of students.

\section{REFERENCES}

Amir, A. (2013). Pengembangan Profesionalisme Guru dalam Pembelajaran melalui Model Lesson Study. Logaritma, 1(2).

Annisa, F. (2017). Internal Relationship Locus of Control and Parent's Support for Work Readiness of Vocational High School (SMK) Students "SMK 1 Tenggarong", Journal of Psychologists, 5(1), 85-95.

BPS. (2016). Survei Angkatan Kerja Nasional. Jakarta: Badan Pusat Statistik.

Friedman. (2008) . Keperawatan Keluarga Teori dan Praktik. Jakarta: EGC.

Fitriyanto, A. (2006). Ketidakpastian Memasuki Dunia Kerja Karena Pendidikan. Jakarta: Rineka Cipta.

Volume 3, Number 1, May 2020 
Jalal, F. (2007). Sertifikasi Guru untuk Mewujudkan Pendidikan yang Bermutu. Medan: Universitas Negeri Medan.

MONE. (2003). Undang-Undang No. 20 tahun 2003 Tentang Sistem Pendidikan Nasional. Jakarta: Ministry of National Education.

Kunandar. (2007). Guru Profesional Implementasi Kurikulum Tingkat Satuan Pendidikan (KTSP) dan Sukses dalam Sertifikasi Guru. Jakarta: PT. Rajagrafindo Persada.

Lee, S., \& Detels, R. (2007). The Effects of Social Support on Mental and Behavioral Outcomes among Adolescents with Parents with HIV/AIDS. Journal of Public Health, 37(2), 216-223.

Makki, B. I., Salleh, R., Memon, M. A., \& Harun, H. (2015). The relationship between work readiness skills, career self-efficacy and career exploration among engineering graduates: A proposed framework. Research Journal of Applied Sciences, Engineering and Technology, 10(9), 1007-1011.

Marsudi, \& Strain. (2010). Psikologi Pendidikan dan Bimbingan. Surakarta: UNM Press. Mariah, S., \& Sugandhi. (2010). Kesenjangan soft skills lulusan SMK dengan Kebutuhan Tenaga Kerja di Industri. Jurnal Inovasi dan Perekayasa Pendidikan, 22, 1-22.

Sofyan, H. (1991). Kesiapan Kerja Siswa STM Sejawa. Laporan Penelitian. FPTK IKIP Yogyakarta.

Sugihartono. (1991). Aspirasi Siswa terhadap Pekerjaan dan Prestasi Akademik Kaitannya dengan Kesiapan Memasuki Dunia Kerja pada Siswa Sekolah Kejuruan di Daerah Istimewa Yogyakarta. Laporan Penelitian. Yogyakarta: IKIP Yogyakarta.

Sukardi, D. K. (2008). Psikologi Pemilihan Karier. Indonesia: Ghalia.

Winkel, W. S. (2014). Psikologi Pengajaran. Jakarta: Grasindo. 
